\title{
APLIKASI PENENTUAN PRIORITAS KRITERRIA PEMILIHAN RUMAH KOST BERBASIS ANALYTICAL HIERARCHY PROCESS (AHP)
}

\author{
Hansen Dharma*1 \\ Wiwin Susanty $\# 2$ \\ Program Studi Sistem Informasi \\ Fakultas Ilmu Komputer \\ Universitas Bandar Lampung \\ Telp. (0721) 701463,
}

\begin{abstract}
Banyak orang yang ingin mencari kost menyepelekan tentang kenyamanan rumah kost tersebut. Padahal rumah kost itu akan menjadi rumah kedua bagi mereka. Banyaknya rumah kost di sekitar kampus tentu akan semakin menyulitkan mereka menentukan pemilihan rumah kost. Maka penulis ingin membuat sistem dan perancangan aplikasi untuk membantu mempermudah semua orang yang ingin mencari rumah kost. Penerapan AHP dalam penelitian ini adalah menentukan urutan prioritas pemilihan rumah kost sesuai kebutuhan masing-masing customer. Kriteria yang penulis gunakan adalah sebagai berikut: Harga sewa kamar, Kondisi rumah kost, Kemudahan akses ke kampus, Fasilitas pendukung kost, serta sarana dan prasarana di sekitar kost, seperti fasilitas angkutan umum, keamana 1 x24 jam, dan strategis adanya banyak makanan.
\end{abstract}

Keyword: Analisis dan perancangan aplikasi,Sistem Informasi,SPK,AHP,dan Pemilihan lokasi kost.

\section{PENDAHULUAN}

\subsection{Latar Belakang}

Hampir seluruh hidup manusia selalu dihadapkan dengan yang namanya pilihan. Manusia dituntut untuk pandai memutuskan suatu pilihan tersebut. Bila manusia menghadapi pilihan maka akan dengan mudah mengambil keputusan tersebut. Tapi jika sudah dihadapi dengan masalah yang lebih rumit / kompleks dan memiliki resiko maka manusia itu membutuhkan alat bantu dalam bentuk analisis yang logis, terukur, dan bersifat ilmiah.

\section{TINJAUAN PUSTAKA DAN LANDASAN TEORI}

\subsection{Tinjauan Pustaka}

Tinjauan pustaka diambil dari beberapa buku, jurnal dan artikel yang berhubungan dengan penelitian ini adalah sebagai berikut:

Penelitian yang dilakukan oleh Wayan R.Susila dan Ernawati Mudadi (Lembaga Riset Perkebunan Indonesia dan Universitas Wijaya Kusuma, Surabaya, Indonesia), tahun 2007, dengan judul "Penggunaan Analytical Hierarchy Process Untuk Penyusunan Prioritas Proposal Penelitian".

\subsection{Landasan Teori}

\subsubsection{Pengertian Aplikasi}

Aplikasi yaitu suatu program komputer yang dibuat untuk mengerjakan atau menyelesaikan masalah-masalah khusus. (Kamus Lengkap Dunia Komputer: 2002).

\subsubsection{Pengertian Sistem}

Menurut Jogiyanto(2005:5), Sistem adalah "Kumpulan dari elemen-elemen yang berinteraksi untuk mencapai suatu tujuan tertentu".

\subsubsection{Informasi}

Menurut Jogiyanto(2005:11), Informasi dapat didefinisikan sebagai“"Data yang diolah menjadi bentuk yang lebih berguna dan lebih berarti bagi yang menerimanya".

\subsubsection{Sistem Informasi}

Menurut Jugiyanto(2005:20), Sistem informasi adalah "Suatu sistem dalam suatu organisasi yang mempertemukan kebutuhan pengolahan transaksi harian, mendukung operasi, bersifat manajerial. Serta kegiatan strategi dari organisasi dan menyediakan pihak luar tertentu dengan laporan-laporan yang diperlukan.

\subsubsection{Pengertian Analytical Hierarchy Process (AHP)}

Analytical Hierarchy Process (AHP) diperkenalkan oleh DR.Thomas L. Saaty di awal tahun 1970. Pada saat itu, AHP dipergunakan 
untuk mendukung pengambilan keputusan pada beberapa perusahaan dan pemerintahan.

\subsubsection{Prinsip-Prinsip Dasar Analytical Hierarchy Process (AHP)}

Skala ukuran panjang (meter), temperatur (derajat), waktu (detik) dan uang (rupiah) telah digunakan dalam kehidupan sehari-hari untuk mengukur bermacam-macam kejadian yang sifatnya fisik. Kita tahu bahwa penerapan seperti itu dapat diterima secara umum.

\subsubsection{Prosedur Analytical Hierarchy Process (AHP)}

Dalam pengambilan keputusan dengan metode AHP langkah-langkah kegiatan yang dilakukan adalah sebagai berikut :

a. Mendefinisikan suatu kegiatan yang memerlukan pemilihan dalam pengambilan keputusannya, seperti : pemilihan fakultas di PTN, pemilihan beberapa kayu komersial, pemilihan lokasi wisata dan sebagainya.

b. Menentukan kriteria dari pilihan-pilihan tersebut terhadap identitas kegiatan membuat hirarkinya.

c. Membuat matriks "pairwise comparison" bardasarkan kriteria focus dengan memperhatikan prinsip-prinsip "comparative judgment".

\subsubsection{Pengertian Rumah Kost}

Menurut Basti, S.Psi (02 April 2009), Rumah Kost adalah hunian yang kita tinggali dan hanya bersifat sementara. Biasanya rumah kost terletak di tempat-tempat yang strategis,seperti di daerah kampus,perkantoran,atau sekola-sekolah.Banyak orang yang memilih untu tinggal di rumah kost daripada pergi-pulang kerumah karena masalah efisiensi biaya dan waktu.

\subsubsection{Definisi Unified Modelling Language (UML)}

Unified Modelling Language (UML) adalah sebuah "bahasa" yang telah menjadi standar dalam industri untuk visualisasi, merancang dan mendokumentasikan sistem piranti lunak. UML menawarkan sebuah standar untuk merancang model sebuah sistem.

\subsubsection{Use Case Diagram}

Use case diagram menggambarkan fungsionalitas yang diharapkan dari sebuah sistem. Yang ditekankan adalah "apa" yang diperbuat sistem, dan bukan "bagaimana". Sebuah use case juga dapat meng-extend use case lain dengan behaviour-nya sendiri. Sementara hubungan generalisasi antar use case menunjukkan bahwa use case yang satu merupakan spesialisasi dari yang lain.

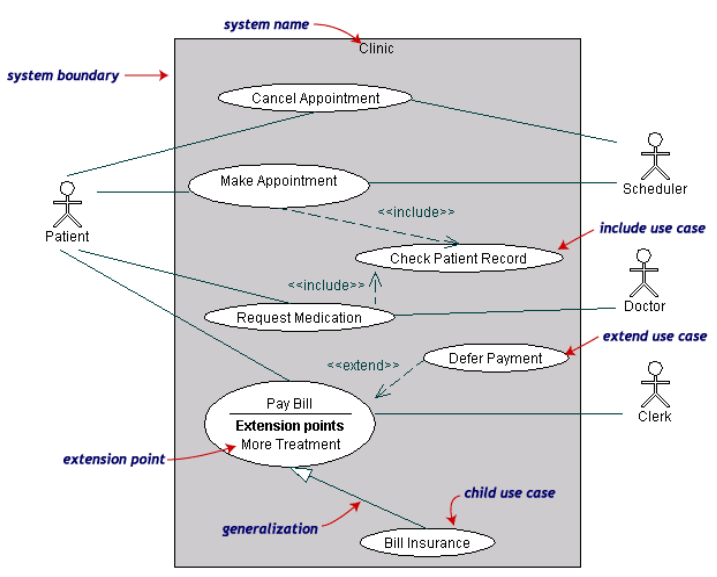

Gambar 1. Use Case Diagram

Hubungan Antar Class

1. Asosiasi, yaitu hubungan statis antar class. Umumnya menggambarkan class yang memiliki atribut berupa class lain, atau class yang harus mengetahui eksistensi class lain. Panah navigability menunjukkan arah query antar class.

2. Agregasi, yaitu hubungan yang menyatakan bagian ("terdiri atas..").

3. Pewarisan, yaitu hubungan hirarkis antar class. Class dapat diturunkan dari class lain dan mewarisi semua atribut dan metoda class asalnya dan menambahkan fungsionalitas baru, sehingga ia disebut anak dari class yang diwarisinya. Kebalikan dari pewarisan adalah generalisasi.

4. Hubungan dinamis, yaitu rangkaian pesan (message) yang di-passing dari satu class kepada class lain. Hubungan dinamis dapat digambarkan dengan menggunakan sequence diagram yang akan dijelaskan kemudian.

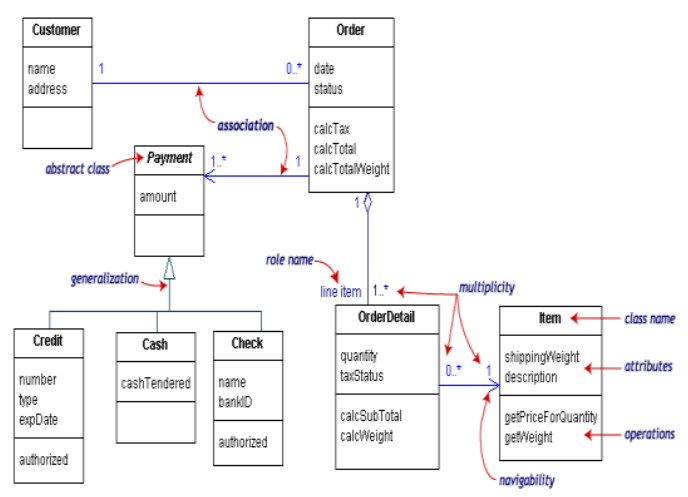

Gambar 2. Class Diagram 


\section{METODOLOGI PENELITIAN}

\section{3 .1 Analisa Kebutuhan}

Metode yang digunakan di dalam penelitian adalah metode deskriptif analitik, dengan menyajikan rangkuman hasil survei dan wawancara yang berupa kuisioner. Kemudian hasil wawancara dengan pakar dijadikan data yang selanjutnya diolah dengan menggunakan pendekatan Analytical Hierarchy Process (AHP) untuk mendapatkan hasil berupa pemilihan rumah kost.

\subsection{Metode Pemilihan Sampel}

Dalam penelitian ini data dan informasi dikumpulkan dari responden ahli dengan menggunakan kuesioner yang disebar pada mahasiswa Universitas Bandar Lampung (UBL). Diharapkan setelah melakukan penelitian ini mahasiswa Universitas Bandar Lampung (UBL) akan mendapatkan keuntungan berupa sistem penunjang keputusan untuk membantu pemilihan rumah kost.

\subsection{Perancangan Penelitian}

Dalam penelitian ini akan dilakukan beberapa tahapan, dimana tahapan ini dapat dilihat pada gambar 3, pada tahapan pertama diawali dengan menentukan kriteria inputan dan output, dari variabel input dan output tersebut dibuat matriks berpasangan, kemudian membuat matriks nilai kriteria, selanjutnya membuat matriks penjumlahan setiap baris, membuat matriks penjumlahan setiap baris, dan menghitung rasio konsistensi, terakhir akan didapatkan hasil urtan nilai pemilihan rumah kost.

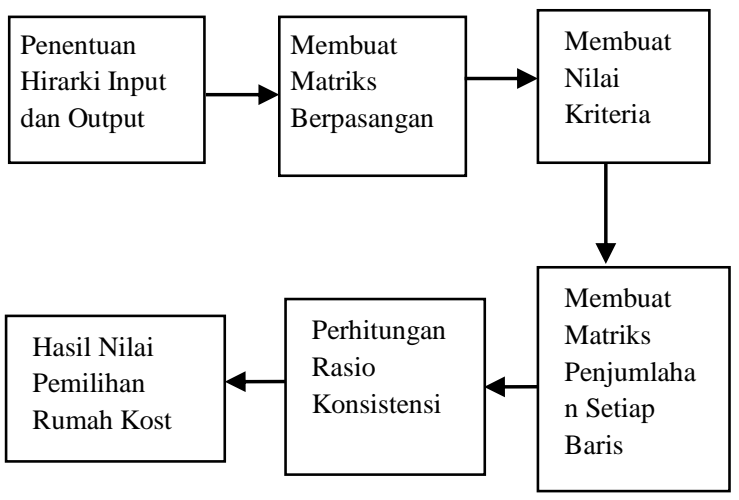

Gambar 3 Tahapan tahapan penelitian untuk pemilihan rumah kost di sekitar Universitas Bandar Lampung Analitycal Hierarchy Process (AHP)

\subsubsection{Penentuan Hirarki Input dan Outtput}

Pada gambar 4 dibawah ini, menunjukan skema hirarki untuk pemilihan rumah kost di Universitas Bandar Lampung, adapun yang menjadi kriteria test untuk menjadi pemilihan rumah kost pada Universitas Bandar Lampung terdiri lokasi, fasilitas, biaya, nyaman, dan lingkungan.

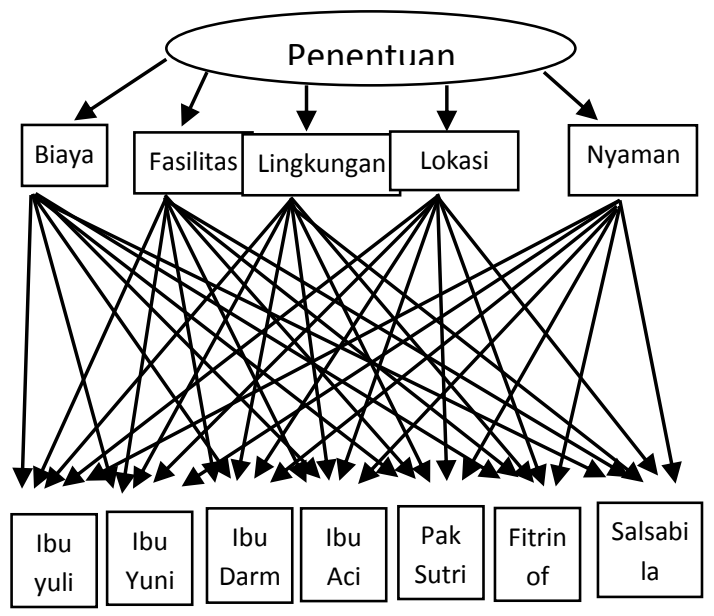

Gambar 4. Skema Hirarki Pemilihann Rumah Kost di Universitas Bandar Lampung

Gambar 4 merupakan gambar Struktur Hirarki Analytical Hierarchy Process (AHP) yang dimana ada tujuan, beberapa criteria yang sudah di dapatkan melalui 50 kuisioner dan alternative rumah kost yang di tuju.

\section{Unified Modelling Languange (UML) Diagram}

\section{Desain Use Case Diagram}

Diagram use case menggambarkan interaksi antara sistem dan pengguna.

Berikut adalah bagan use case yang digunakan pada penelitian ini:

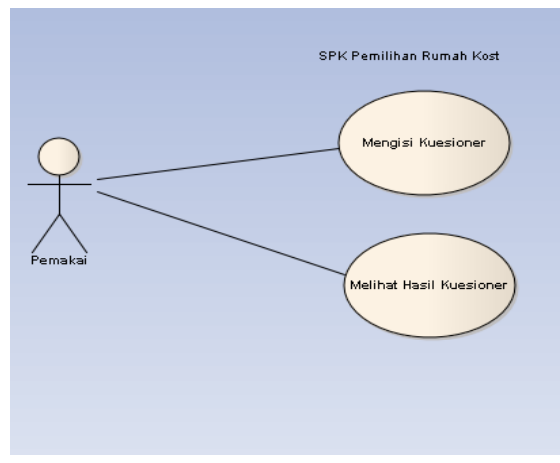

Gambar 5 Use Case Diagram

\section{Desain Sequence Diagram}

Sequence diagram menggambarkan interaksi antar objek pada suatu sistem yang dikembangkan. Sequence diagram memiliki dua dimensi utama yaitu dimensi vertikal yang menggambarkan waktu yang terkait terhadap sebuah objek dan dimensi horizontal 
menggambarkan objek-objek yang terkait pada masing-masing diagram.

Objek pemakaian akan menjawab kuisioner yang telah diberikan, kemudian program yang akan melakukan kalkulasi atau perhitungan menggunakan AHP, hasil perhitungan menggunakan AHP akan ditampilkan ke objek pemakai.

\section{Desain Activity Diagram}

Activity diagram menggambarkan berbagai flow (aliran) aktivitas dalam sistem yang sedang dirancang. Activity diagram juga dapat menggambarkan awalan suatu aktivias, percabangan (decission) sampai pada tahapan akhir suatu aktivitas sistem. Berikut adalah Activity Diagrams yang menggambarkan aktivitas yang terjadi pada aplikasi ini:

\section{Desain Class Diagram}

Class diagram menggambarkan struktur dan deskripsi class, package dan objek beserta hubungan satu sama lain. Pada Penelitian ini dapat digambarkan class diagram sistem sebeagai berikut:

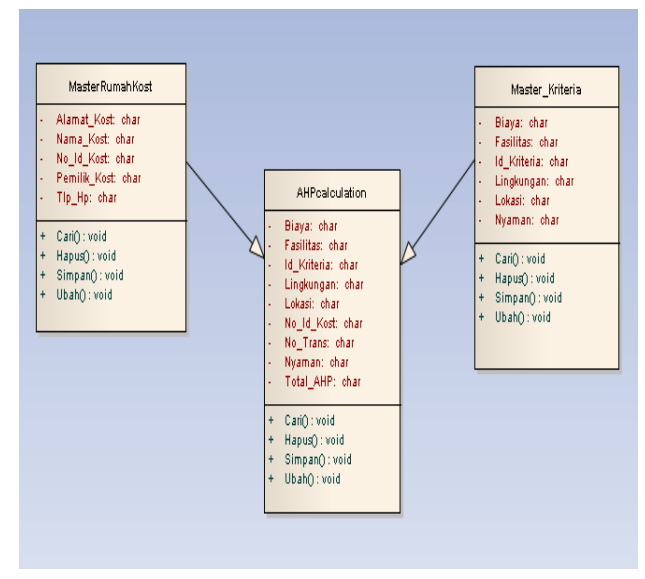

Gambar 6 Class Diagram

Pada gambar diatas menggunakan Class Diagram atau gambar keterhubungan antara class. Class diagram ini yang akan menjadi objek table dalam program.

\section{HASIL DAN PEMBAHASAN}

\subsection{Pembahasan}

\section{Kamus Data}

Berikut adalah kamus data yang dibutuhkan untuk mendukung sistem yang digunakan seperti Field adalah nama database yang di gunakan,Type adalah tipe dari nama yang akan di gunakan setelah database jadi, Values adalah banyaknya atau jumlah maksimal huruf yang akan di masukan.

\section{Menu Login}

Menu login ini berfungsi untuk menjaga keamanan data, untuk masuk ke menu utama, anda harus memasuki username dan password yang benar, jika salah maka tidak akan masuk ke menu utama. Tampilan menu login ini dapat dilihat pada gambar 13:

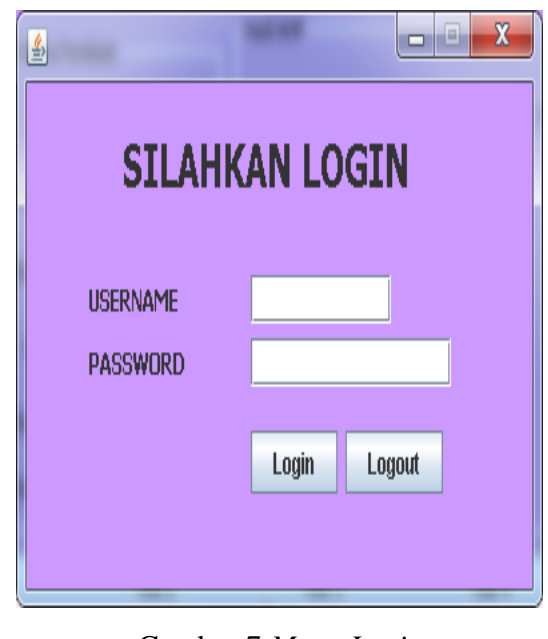

Gambar 7 Menu Login

\section{Menu Utama}

Menu utama ini merupakan program utama yang berisi beberapa submenu antara lain data master, data perhitungan AHP penyeleksian, laporan, dan about. Tampilan menu utama ini dapat dilihat pada gambar 14:

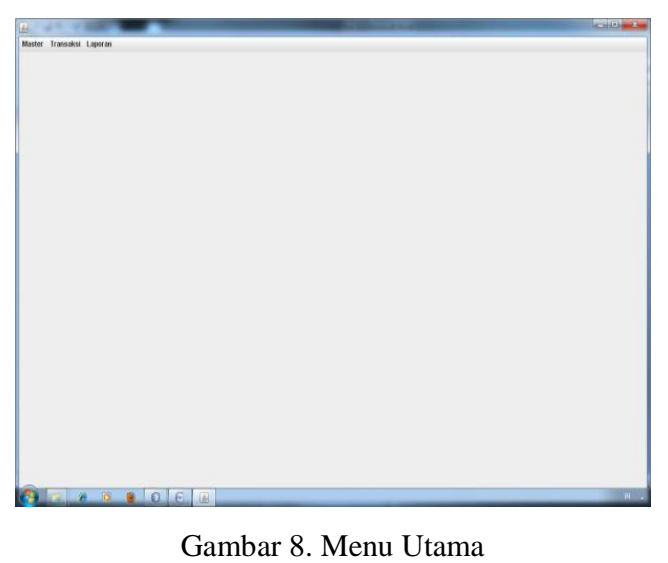

\section{Menu Data Master}

Pada menu master terdiri dari submenu yatu: Input Data Master Rumah Kost dan Master Kriteria. Pilih submenu yang ingin ditampilkan dengan cara klik from yang ingin ditampilkan. 


\section{Master Rumah Kost}

Untuk menampilkan fasilitas form data master rumah kost dengan cara:

a. Pilih form master rumah kost pada menu utama, kemudian klik dan akan muncul form master rumah kost.

b. Klik tombol baru, pada program ini field no_id_kost akan otomatis.

c. Isi data sesuai dengan field yang tersedia.

d. Jika sudah lengkap, klik tombol simpan jika ingin menyimpan data.

e. Klik ubah untuk mengubah data.

f. Dan hapus jika ingin menghapus data.

g. Klik tombol kluar untuk keluar dari form master rumah kost.

h. Berikut tampilan form master rumah kost bisa dilihat pada gambar 9.

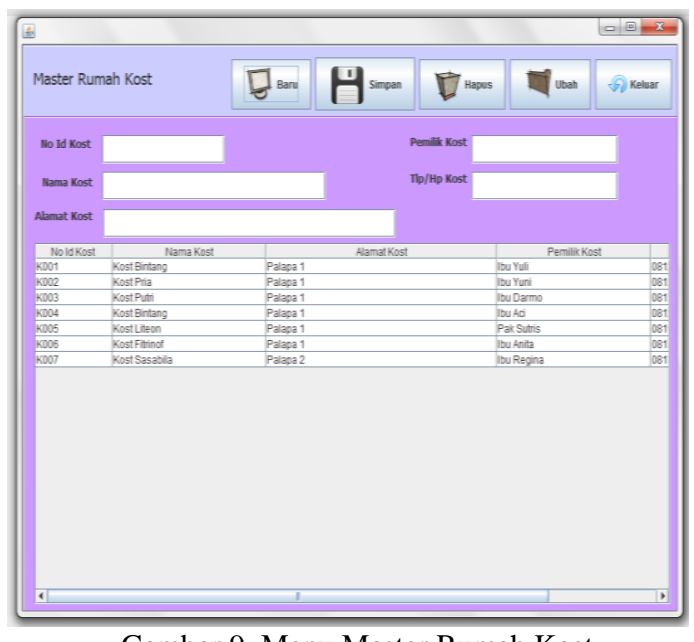

\section{Menu Perhitungan AHP}

Menu yang terdapat dalam menu data perhitungan digunakan untuk memproses penentuan rumah kost, terdiri dari form perhitungan nilai AHP rumah kost dan perhitungan nilai kriteria.

\section{Perhitungan Nilai Kriteria Penentuan Rumah}

Kost

Untuk menampilkan fasilitas form perhitungan nilai kriteria dengan cara :

a. Pilih form perhitungan nilai AHP pada menu utama, kemudian klik dan akan muncul form perhitungan nilai kriteria.

b. Isi data sesuai dengan field yang tersedia.

c. Jika sudah lengkap, klik tombol hitung untuk menjumlahkan perhitungan kriteria AHP.

d. Klik tombol simpan untuk menyimpan data.

e. Klik tombol kluar dari form perhitungan kriteria penentuan rumah kost.

f. Berikut tampilann form perhitungan kriteria penentuan rumah kost dilihat pada gambar 10 .

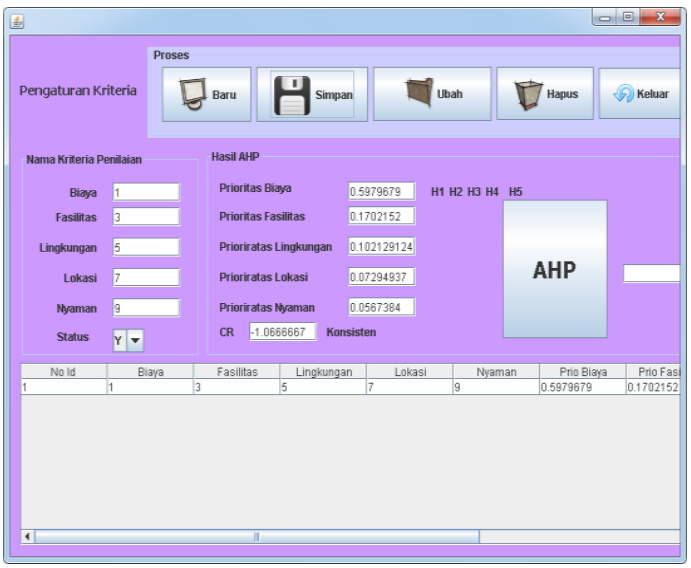

Gambar 10 Perhitungan Nilai Kriteria Pemilihan Rumah Kost

\section{Form Laporan data Rumah Kost}

Untuk menampilkan fasilitas form laporan data pelamar dengan cara :

a. Pilih form laporan data rumah ksot pada menu utama, kemudian klik dan akan muncul form laporan data rumah kost.

b. Klik tombol print untuk cetak laporan data rumah kost yang di terima.

c. Klik tombol kluar jika ingin kluar dari laporan data rumah kost.

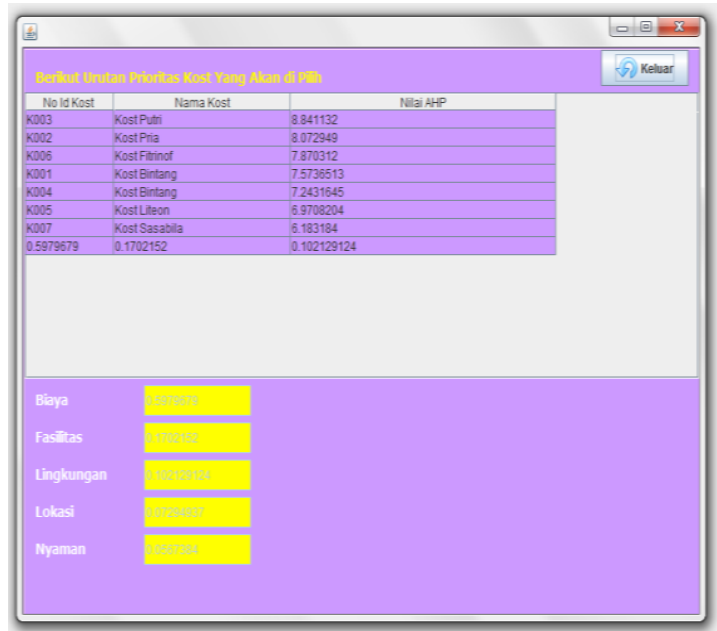

Gambar 11 Laporan Data Rumah Kost

\section{Penguji Aplikasi Penentuan Rumah Kost}

Setelah di lakukan aplikasi ini di sebarkan 15 kuisioner apakah aplikasi ini dapat membantu pencari rumah kost untuk memilih rumah kost sehinga pemiliha rumah kost menjadi lebih mudah. 




Gambar 12. Diagram Batang Kuesioner Tingkat Kesulitan Pemilihan Rumah Kost

Dari grafik di atas dapat di ketahui bahwa $80 \%$ responden lebih mudah menentukan pencarian rumah kost.

\section{KESIMPULAN DAN SARAN}

\subsection{Kesimpulan}

Berdasarkan tugas akhir tentang aplikasi berbasis Analytical Hierarchy Process (AHP), maka dapat di ambil kesimpulan bahwa berdasarkan hasil survey dengan kuesioner, aplikasi yang dibuat dengan menggunakan teori analytical hierarchy process (AHP) dapat mengurangi tingkat kesulitan dalam pemilihan rumah kost.

\subsection{Saran}

Penulis mengharapkan penelitian ini dapat dikembangkan lebih lanjut diantaranya:

1. Pengembangan sistem seperti membuat jalur online supaya mahasiswa dapat memilih rumah kost yang sesuai.

2. Lebih mengembangkan pemilihan rumah kost dengan sistem pakar.

\section{DAFTAR PUSTAKA}

1. Ari.S.P., Mulya.A.A. 2008."Sistem Pengambilan Keputusan Pemilihan Jurusan di Perguruan Tinggi”, Fakultas Matematika dan Ilmu Pengetahuan Alam, Institut Teknologi Sepuluh November: hal. 1-14.

2. Haas and Meixneer, "An Illustrated Guide to the Analytical Hierarchy Process", http://www.boku.ac.at/mi/

3. Ibrahim R. 1997. Bandung: PT. Citra Aditya bakti.

4. Jogiyanto(2005:5)
5. Latifah, Siti. 2005. "Prinsip - prinsip dasar Analytical Hierarchy Process". Jurnal Studi Kasus Fakultas Pertanian, Universitas Sumatera Utara (USU), Medan.

6. Mulyono, Sri. 1996. Teori Pengambilan Keputusan. Jakarta: Fakultas Ekonomi Universitas Indonesia.

7. Johanes Sinaga (Departemen Matematika, Fakultas Matematika dan Ilmu Pengetahuan Alam, Universitas Sumatra Utara, Medan), tahun 2009, dengan judul "Penerapan Analytical Hierarchy Process (AHP) Dalam Pemilihan Perusahaan Badan Usaha Milik Negara (BUMN) Sebagai Tempat Kerja Mahasiswa Universitas Sumatera Utara (USU)".

8. Purwono, 2002Kamus Lengkap Dunia Komputer: 2002.

9. Pustaka Binaman Pressindo.

10. Saaty, T.L. 1987. Uncertainty and rank order in the analytic hierarchy process.

11. European Journal of Operational Research 32:27-37.

12. Supranto. J. 1992 Rineka Cipta.

13. Susila, W dan Munadi, Ernawati. 2007. "Penggunaan Analytic Hierarchy ProcessUntuk Penyusunan Prioritas Proposal Penelitian", Jurnal Informatika Pertanian Vol. 16, No. 2.Departemen Pertanian.

14. Teknomo, K., Siswanto, H. dan Yudhanto, S. A. 1999. "Penggunaan Metode Analytic Hierarchy Process dalam Menganalisa Faktor-Faktor yang MempengaruhiPemilihan Moda ke Kampus". Jurnal Dimensi Teknik Sipil, Universitas Petra 1: 